Organic Analysis 1958" is very much to the point and gives good coverage to the work in this very important field, while the article dealing with "Progress in Qualitative Inorganic Analysis 1958" is written as a piece of special pleading for the replacement of classical techniques by others recommended by the author without sufficient explanation for his choice. The bibliography covers a wide range and has more references to European work than is sometimes found in American publications. This is probably a reflexion of the world-wide interest in microchemistry. There appears to be no reference in any of the sections to the determination of traces of residual pesticides in animal and plant tissues. This subject, which has a literature as extensive as the whole of the volume under review, would have added to the general value of the collection and could have provided material for discussion of the determination of sub-microgram quantities of organic compounds. The short section on equipment refers exclusively to American instruments. Subjects covered are, microscopy, fractionation and inorganic, organic and biochemical analysis. On the whole this is a useful collection of papers.

\section{Russian Review of Biology}

The Institute of Biology, in collaboration with tho Department of Scientific and Industrial Research, is to publish an Fnglish translation of the Russian Review of Biology (Oliver and Boyd, Ltd. £9 for nine numbers in all for 1959 and 1960, and $£ 610 s$. per annum for six numbers thereafter). The Russian journal has been running for many years, and contains summaries, each dealing with progress in a specific topic of biological research. The first trans. lated number starts with a polemical discussion of a work by Lenin in relation to Soviet materialist biology. This is followed by review articles on two enzymes (polynucleotide phosphorylase and xanthine oxidase), the use of enzymes in biological investigation, erythrocyte sedimentation and, finally, the immunological reaction in embryos and new-born animals. There are extensive bibliographies, which, incidentally, indicate tho familiarity of Russian biologists with research throughout the world. This new translation will help to acquaint more Englishspeaking workers with the biological research going on in Russia. Under 'current events' there is an appreciative account of a visit by Kh. S. Koshtoyants to some of the biology departments at Cambridge.

\section{Sarawak Museum}

THE Sarawak Museum Journal, Vol. 8, of June 1958 is edited by Mr. Tom Harrisson, Government ethnologist and curator of the Sarawak Museum, and includes some characteristic forthright editorial comments. The volume is divided into five partsthe past, the present, some recent Borneo writing reviewed, Borneo plants and animals, and climate. Although the majority of the articles are of interest chiefly to those who live in Borneo, others, such as a paper on pollen from the South China Sea by Dr. F. R. Van Veen, are of more general application.

\section{Bronze Figures from Nigeria}

An illustrated article on some bronze figures from Ita Yemoo, Ife, Nigeria, by Frank Willett, the archæologist of the Department of Antiquities, appeared in the November 1959 issue of Man. The finds were unearthed by chance, and luckily
Bernard Fagg, the director of antiquities, happened to be in the vicinity. As a result, all particulars of their occurrence, etc., were collected, and the finds themselves carefully preserved. Like the pottery figures discovered some time earlier, they are of great interest, though, perhaps, not so beautiful. An interesting fact is that five of the bronze heads are gagged, and they probably represent victims for sacrifice in view of the sherds of a ritual pot found nearby. Doubtless all these various art discoveries in Nigeria will be published in book form in due course.

\section{Mathematics and Children}

As article by Z. P. Dienes, lecturer in mathematics in the University of Leicester, in Educational Research shows that there are ways in which mathematical concepts can be caused to develop in children so that the techniques they learn are preceded by an understanding of the corresponding mathematical structures (Educat. Res., 2, No. 1; Nov. 1959). Dienes's scheme has not yet been tried out under actual school conditions, but it is possible to state some qualitative results derived from trials in a number of schools. Schemes of individual mathematical discovery can be worked in large unstreamed classes throughout junior schools ; a large majority of normal children can understand the complex workings of the four rules of arithmetic in the decimal and other systems; normal 10-year-old children can learn the use of brackets, the properties of the square, the solution of linear and quadratic equations and the factorizing of quadratic functions, if approached constructively.

It is possible to give children leaving junior school a solid body of practical experiences, impossible to obtain from real-life situations, on which an extensive secondary school curriculum can be based. There are almost limitless possibilities for enlarging the junior school syllabus, by including such topics as theory of groups, usually reserved for university honours courses. There is sufficient evidence to suggest that mathematics can be introduced to a larger section of the child population than had hitherto been thought practicable or possible. This is done by co-ordinating the teacher's work with the natural process of concept formation in the child. It is a challenge to the teaching profession to devise ways in which this much larger body of children can be drawn into the mathematical workshop. By doing so, a large potential of future mathematicians, scientists, and technicians would be created whose practical bias is likely to make them extremely useful members of an in. creasingly technological society.

\section{Preventing Evaporation from Reservoirs}

VAST quantities of water evaporate from storages located almost everywhere in Australia. Much of the pastoral land lies in regions where evaporation from a free water surface exceeds $6 \mathrm{ft}$. a year, and annual losses of $8 \mathrm{ft}$. are not uncommon inland. The Mansfield process, devised by Mr. W. W. Mansfield of the Division of Physical Chemistry of the Commonwealth Scientific and Industrial Research Organization (Australia), has provided pastoralists and farmers with a simple method of cutting these enormous losses by at least a quarter. The process involvos spreading a very thin film of hexadeconal (a pure form of cetyl alcohol) over the surface of stock tanks and small farm dams. The film is continuously 